\title{
"Hunger and rage (and the virus) are human things": reflections on solidarity in times of Covid-19
}

\author{
"A fome e a raiva (e o vírus) é coisas dos \\ home": reflexões sobre participação \\ social em tempos de Covid-19
}

\author{
Juliana Theodora Cunha de OLIVEIRA ${ }^{1}$ (D) 0000-0003-4671-372X

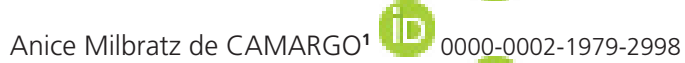 \\ Beatriz Oliveira Blackman MACHADO2 ID) 0000-0001-7749-8407 \\ Anelise Rizzolo de OLIVEIRA ${ }^{3}$ (ID) 0000-0002-4683-8736 \\ Giovanna Medeiros Rataichesck FIATES 1 (ID) 0000-0001-7830-1215 \\ Francisco de Assis Guedes de VASCONCELOS' (ID) 0000-0002-6162-8067
}

\section{A B S T R A C T}

Brazil confirmed the first Covid-19 case in February 2020, in a framework of a massive introduction of neoliberal policies which worsen the potential to tackle the problem, especially, health, food and nutrition security and social assistance policies for vulnerable populations. In the absence of the State, civil society initiated a process of (re)constructing social participation actions to fight hunger in Brazil, either spontaneously or through organizations.

\section{Objective}

To identify and reflect about civil society's initiatives to curb hunger in connection with the Covid-19 pandemic in Brazil.

\footnotetext{
1 Universidade Federal de Santa Catarina, Programa de Pós-Graduação em Nutrição. Campus Universitário Reitor João David Ferreira Lima, Bairro Trindade, Florianópolis, 88040-900, Santa Catarina, SC, Brasil. Correspondence to: FAG VASCONCELOS. E-mail: $<$ f.vasconcelos@ufsc.br>.

2 Escola de Governo Fiocruz, Programa de Residência Multiprofissional em Saúde da Família com ênfase em Saúde da População do Campo. Brasília, DF, Brasil.

${ }^{3}$ Universidade de Brasília, Faculdade de Ciências da Saúde, Mestrado Profissional em Sustentabilidade junto a Povos e Territórios Tradicionais. Brasília, DF, Brasil.
}

How to cite this article

Oliveira JTC, Camargo AM, Machado BOB, Oliveira AR, Fiates GMR, Vasconcelos FAG. "Hunger and rage (and the virus) are human things": reflections on solidarity in times of Covid-19. Rev Nutr. 2021;34:e200183. https://doi.org/10.1590/1678$9865202134 \mathrm{e} 200183$ 


\section{Methods}

In order to identify society's initiatives to fight hunger, two independent systematic searches were conducted in the Google ${ }^{\circledR}$ search engine using the following keywords: "covid civil society initiatives" and "hunger pandemic solidarity campaign".

\section{Results}

Fourteen nationwide civil society-promoted initiatives were identified, that among their objectives aimed at fostering collective funding to purchase and distribute foods.

\section{Conclusion}

Brazilian society has been historically sensitive to the hunger problem and shows solidarity as a social value. Nevertheless, the State is legally bound to provide food, as a social right.

Key-words: Covid-19. Food and Nutrition Security. Human Right to Adequate Food. Social Mobilization. Social Participation.

\section{R E S U M O}

O Brasil confirma o primeiro caso de Covid-19 em fevereiro de 2020 num contexto de franca implantação de políticas neoliberais, que pioram a capacidade de enfrentamento do problema, em especial, as politicas de saúde, segurança alimentar e nutricional e assistência social destinadas às populações vulneráveis. Na ausência do Estado, a sociedade civil de forma espontânea ou organizada, iniciou um processo de (re)construção de ações de participação social para o combate à fome no Brasil.

\section{Objetivo}

Mapear e refletir sobre as iniciativas da sociedade civil para o combate à fome no contexto da pandemia de Covid-19 no Brasil.

\section{Métodos}

Para identificar as iniciativas da sociedade para o combate à fome foram conduzidas duas buscas sistemáticas independentes na plataforma Google®, utilizando as palavras-chave: "iniciativas sociedade civil covid" e "fome pandemia campanha solidariedade".

\section{Resultados}

Foram localizadas quatorze iniciativas da sociedade civil de abrangência nacional que têm entre seus objetivos promover campanhas de financiamento coletivo para aquisição e distribuição de alimentos.

\section{Conclusão}

Historicamente, a sociedade brasileira é sensível ao tema do combate à fome e presta solidariedade como um valor social. Contudo, cabe ao Estado a obrigação legal do cumprimento da alimentação enquanto um direito de cidadania.

Palavras-chave: Covid-19. Segurança Alimentar e Nutricional. Direito Humano à Alimentação Adequada. Mobilização Social. Participação Social.

\section{INTRODUCTION}

The expansion of the new Coronavirus (Covid-19, Coronavirus Disease 2019) pandemic in Brazil, with the exponential increase of disease cases, starting February 2020, associated with the current scenario of dismantling the State and the implementation of neoliberal policies, deepens social inequalities and rekindles an old Brazilian ghost: Hunger [1].

Brazil, despite being off the 2014 Food and Agriculture Organization of the United Nations (FAO) Hunger Map, has been showing discontinuity since 2016 of public policies to face the problem, weakening the systems that ensure rights, and in particular, health, social assistance and food and nutrition security policies for vulnerable populations [2-4]. 
The effects of the 2016 Constitutional Amendment ActNo. 95 and the current management policies of the federal government have been decisive for the straining of the Government Unified Health System (SUS) in the face of the pandemic [5]. Globally, the most successful countries in coping with Covid-19 are those with structured public health systems and/or associated with integrated health networks (public/private) with coordinated command for planning, management and control of sanitary, social and political measures [6].

The application of measures to contain the disease - social distance, home isolation and quarantine, combined with the delay in governmental actions for economic and social protection, aggravated the increase in the unemployment rate and the decrease in income, which had been accumulating in Brazil since 2014 and accelerating since 2016 [7-9]. According to the Instituto Brasileiro de Geografia e Estatística (IBGE, Brazilian Institute of Geography and Statistics), unemployment rate, which in the first quarter of 2020 was $12.6 \%$ (12.85 million unemployed), will possibly increase in the following months, intensifying the phenomenon of cyclical hunger generated by the disease containment measures $[10,11]$.

In Brazil, since 2016, the set of policies and programs aimed at ensuring Food and Nutrition Security (SAN, Segurança Alimentar e Nutricional) with a view to ensuring the Human Right to Adequate and Healthy Food (DHAAS, Direito Humano à Alimentação Adequada e Saudável) has undergone progressive dismantling [8]. The main governmental programs of the National Food and Nutrition Security Policy (PNSAN, Politica Nacional de Segurança Alimentar e Nutricional) aimed at socially vulnerable populations such as the Food Purchase Program (PAA, Programa de Aquisição de Alimentos), Popular Restaurants, the National School Feeding Program (PNAE, Programa Nacional de Alimentação Escolar) and the Bolsa Familia Program, presented a drop in investments, with changes in the inclusion, scope and transparency criteria of the management process $[9,12]$.

The worsening of the situation of Food and Nutrition Insecurity (FNI) in part of the Brazilian population has been signaled by scientific entities, scientific associations, Non-Governmental Organizations and investigators based on analyses and technical reports on complaints of violation of rights and absence of actions to comply with the DHAA $[4,13-15]$. The entire scenario generated by the pandemic underscores the urgency and primacy of actions to face the economic slowdown that is rapidly expanding and deepening, including unemployment, poverty and other forms of social suffering [16].

In the absence of actions and public policies to mitigate the effects of the pandemic, civil society in a spontaneous or organized way, started a process of (re) construction of solidarity actions to fight hunger, in the light of the social movement created by Herbert de Souza, Betinho, in the early 1990s $[17,18]$.

Historically, the existence of the National Council for Food and Nutrition Security (Consea, Conselho Nacional de Segurança Alimentar e Nutricional) (2003 - 2019) inserted the theme of Combating Hunger in the field of public policies and social rights and revealed other arrangements in society to face the current situation. Today, new narratives, actors and concerns emerge that, in the 1990s, were not consolidated. Fundamental social protection elements are added in the face of the pandemic, with emphasis on partnerships from non-governmental sectors and, above all, local-based social mobilization that promotes visibility, cooperation and support on several fronts $[19,20]$. The purpose of this article is to present a brief description-reflection on civil society actions to fight hunger in connection with the Covid-19 pandemic in Brazil.

\section{METHODS}

To identify the initiatives to fight hunger promoted by civil society, systematic searches were conducted on the Google ${ }^{\circledR}$ platform. The google.com page was accessed through an anonymous window, 
where two independent surveys were carried out using the combinations of keywords in Portuguese: "covid civil society initiatives" and "hunger pandemic solidarity"campaign ("iniciativas sociedade civil covid" and "fome pandemia campanha solidariedade"). Without applying a date limit, the first 20 results (links) were accessed to identify those that compiled solidarity actions during the Covid-19 pandemic. No links resulting from the survey were sponsored (i.e. highlighted at the top of the search results). Two investigators reviewed all the actions registered in each of the 20 links, excluding those not related to food supply and with no national coverage. Actions considered at a national level were those with a wider scope than local actions (e.g. neighborhoods or communities), municipal or just one State of the federation.

The actions included had their available information entered in a database for further characterization and analysis. The survey was carried out in June 2020 and did not intend to exhaustively cover all of them, only those having a national scope. Initiatives disseminated exclusively through social media could not be identified with the search strategy adopted.

\section{R E S U L T S}

The systematic survey method led to the identification of fourteen nationwide civil society initiatives in the fight against Covid-19 which, among several objectives, is the fostering of collective funding campaigns for the acquisition and distribution of food (Chart 1). The disclosure of ten of the fourteen actions occurred, in addition to the identified internet pages, also through the social media such as Instagram ${ }^{\circledR}$, Facebook $^{\circledR}$, Twitter $^{\circledR}$, YouTube ${ }^{\circledR}$, and Linkedin ${ }^{\circledR}$.

Chart 1. Civil society actions to fight hunger in connection with the Covid-19 pandemic.

\begin{tabular}{|c|c|c|c|c|}
\hline Initiative & Responsible & Beneficiaries & Action & Coverage \\
\hline \#FavelasContraOVírus & Central Única das Favelas & Slum dwellers & $\begin{array}{l}\text { Awareness actions, food } \\
\text { and alcohol gel }\end{array}$ & National \\
\hline Apoie os povos indígenas & $\begin{array}{l}\text { Articulação dos Povos Indí- } \\
\text { genas do Brasil }\end{array}$ & Indigenous villages & $\begin{array}{l}\text { Food, medicine and hygiene } \\
\text { supplies }\end{array}$ & National \\
\hline \#DesafioCorona & Individuals and legal entities & $\begin{array}{l}\text { Families economically } \\
\text { affected by the crisis }\end{array}$ & $\begin{array}{l}\text { Food,hygiene and cleaning } \\
\text { supplies }\end{array}$ & National \\
\hline $\begin{array}{l}\text { Ação da Cidadania contra } \\
\text { o Coronavírus }\end{array}$ & $\begin{array}{l}\text { Associação Comitê Rio da } \\
\text { Ação da Cidadania Contra } \\
\text { a Fome a Miséria e Pela } \\
\text { Vida }\end{array}$ & $\begin{array}{l}\text { Families in large urban } \\
\text { centers dependent on } \\
\text { informal work }\end{array}$ & $\begin{array}{l}\text { Food and basic food } \\
\text { baskets }\end{array}$ & $\begin{array}{l}26 \text { States and } \\
\text { Federal District }\end{array}$ \\
\hline $\begin{array}{l}\text { Campanha de doações } \\
\text { COVID-19 }\end{array}$ & $\begin{array}{l}\text { Ação Social para Igualdade } \\
\text { das Diferenças }\end{array}$ & $\begin{array}{l}\text { Families of people with } \\
\text { disabilities in situations } \\
\text { of extreme vulnerability }\end{array}$ & $\begin{array}{l}\text { Basic food baskets, personal } \\
\text { hygiene kits and medicines }\end{array}$ & 16 States \\
\hline $\begin{array}{l}\text { Solidariedade aos grupos } \\
\text { mais vulneráveis }\end{array}$ & $\begin{array}{l}\text { Central de Movimentos Po- } \\
\text { pulares }\end{array}$ & Highly vulnerable families & $\begin{array}{l}\text { Basic food baskets and } \\
\text { perishable products }\end{array}$ & 16 States \\
\hline $\begin{array}{l}\text { Campanha Movimento } \\
\text { de Luta nos Bairros, Vilas } \\
\text { e Favelas }\end{array}$ & $\begin{array}{l}\text { Movimento de Luta nos } \\
\text { Bairros, Vilas e Favelas }\end{array}$ & Homeless families & $\begin{array}{l}\text { Basic food baskets and } \\
\text { cleaning supplies }\end{array}$ & $\begin{array}{l}15 \text { States and Federal } \\
\text { District }\end{array}$ \\
\hline Corona no Paredão & ONG Gerando Falcões & $\begin{array}{l}\text { Families from vulnerable } \\
\text { communities }\end{array}$ & Digital basic food baskets & 12 States \\
\hline $\begin{array}{l}\text { Fundo de emergência } \\
\text { para Sem-Tetos afetados } \\
\text { pelo coronavirus }\end{array}$ & $\begin{array}{l}\text { Movimento dos Trabalha- } \\
\text { dores Sem Teto }\end{array}$ & $\begin{array}{l}\text { Homeless individuals and } \\
\text { residents of peripheries }\end{array}$ & Basic food baskets & $\begin{array}{l}10 \text { States and Federal } \\
\text { District }\end{array}$ \\
\hline
\end{tabular}


Chart 1. Civil society actions to fight hunger in connection with the COVID-19 pandemic.

\begin{tabular}{|c|c|c|c|c|}
\hline Initiative & Responsible & Beneficiaries & Action & Coverage \\
\hline Mutirão do Bem Viver & Sociedade do Bem Viver & $\begin{array}{l}\text { Homeless population, } \\
\text { peripheral residents and } \\
\text { vulnerable territories in the } \\
\text { countryside and forests }\end{array}$ & $\begin{array}{l}\text { Agroecological food } \\
\text { baskets, essential items }\end{array}$ & 8 States \\
\hline $\begin{array}{l}\text { Campanha da Rede } \\
\text { Nacional de Acolhimento } \\
\text { LGBTQIA+ do Brasil }\end{array}$ & Pro LGBT entities+ $\mathbf{1}$ & $\begin{array}{l}\text { LGBTQIA+ population } \\
\text { dependent on informal } \\
\text { work or who is in a host } \\
\text { space }\end{array}$ & $\begin{array}{l}\text { Basic food baskets and } \\
\text { hygiene products }\end{array}$ & $\begin{array}{c}6 \text { States } \\
(\mathrm{BA}, \mathrm{PE}, \mathrm{AM}, \mathrm{MG}, \mathrm{RJ}, \mathrm{SP})\end{array}$ \\
\hline $\begin{array}{l}\text { Doação de alimentos e } \\
\text { materiais de higiene para } \\
\text { quilombolas }\end{array}$ & $\begin{array}{l}\text { Coordenação Nacional de } \\
\text { Articulação das Comuni- } \\
\text { dades Negras Rurais e } \\
\text { Quilombolas }\end{array}$ & $\begin{array}{l}\text { Quilombos affected } \\
\text { by COVID-19, which } \\
\text { are overcoming disaster } \\
\text { situations }\end{array}$ & Food and hygiene supplies & NS \\
\hline TETO Brasil & Organização TETO Brasil & $\begin{array}{l}\text { Communities in a state } \\
\text { of precariousness }\end{array}$ & $\begin{array}{l}\text { Basic food baskets, hygiene } \\
\text { kit and water }\end{array}$ & NS \\
\hline \#EspalheSolidariedade & $\begin{array}{l}\text { Habitat para a Humanidade } \\
\text { Brasil }\end{array}$ & $\begin{array}{l}\text { Families in situations of } \\
\text { social vulnerability }\end{array}$ & $\begin{array}{l}\text { Food, hygiene and cleaning } \\
\text { supplies }\end{array}$ & NS \\
\hline
\end{tabular}

Note: 'Host Homes, Networks for Fighting and Combat LGBT Phobia, Centers for Sociability and Rights of the LGBTQIA + Population.

NS: Not Specified; BA: Bahia; PE: Pernambuco; AM: Amazonas; MG: Minas Gerais; RJ: Rio de Janero; SP: São Paulo; LGBTQIA: Lesbians, Gays, Bisexuals, Transvestites, Transsexuals or Transgenders; ONG: Organização Não Governamental.

The populations served include slum dwellers, homeless people, peripheral residents and vulnerable territories in the countryside and forests, indigenous people, people with disabilities in extreme vulnerability conditions and their families, families who depend on informal work, LGBTQIA + population (Lesbians, Gays, Bisexuals, Transvestites, Transsexuals or Transgenders), street-dwelling families, among others.

Out of the fourteen initiatives, only two existed before the pandemic, the "Mutirão do Bem Viver" and "Teto Brasil". Thirteen operated with cash donations from individuals and/or legal entities, through deposits in bank accounts, or "online collections" for further acquisition and distribution of food. Nine actions disclosed in real time the amount of donations that, at the time of data collection, reached a total of approximately 19 million reais distributed among all the benefits covered by the campaigns.

Only four initiatives estimated the total number of beneficiaries. Two of them pointed out that 267,467 individuals had been helped and the remaining two had helped a total of 7,557 families. Although not all actions informed the States covered, all the units of the Federation were, in some way, reached. Three of the actions also request the involvement of volunteers in their campaigns.

Among all the initiatives - "Mutirão do Bem Viver" stands out, as it is a society action that proposes a new supply dynamic: the short production circuit, dialoguing with the guidelines of the National Food and Nutrition Security Policy encouraging sustainable, decentralized and agro-ecological systems going from production to food distribution [20], and promoting access to adequate and healthy food.

\section{DISCUSSION}

Covid-19 made visible the perverse effects of the weakening of Food and Nutrition Security Program policies in Brazil. Noteworthy is the extinction, on January 1, 2019, of the National Secretariat for Food and Nutrition Security (SESAN, Secretaria Nacional de Segurança Alimentar e Nutricional) and of the National CONSEA, which directly reflected in the increase in practices of violation of the DHAA $[21,22]$. 
In this connection, the pandemic caused by Covid-19 intensified the inequality of access to adequate food by the Brazilian population. The most vulnerable population, in which the spread of the virus is accelerated by poor living and health conditions, feels the threat of hunger intensely $[4,23,24]$. The pandemic has contributed to a worsening of the InSAN situation, in view of the current scenario of increasing poverty and extreme poverty in Brazil [25].

The federal government was inefficient at mitigating the impact of the health crisis generated by Covid-19 and aggravated by the previous social scenario of weakening social rights. In the National Congress, the payment of an emergency aid amounting to half the minimum wage was approved, for informal workers, individual Microentrepreneurs (MEI), self-employed and unemployed [26-28].

Although insufficient, federal congressmen and senators, as a result of strong pressure from civil society movements articulated with the theme of SAN, including the Brazilian Forum on Sovereignty and Food and Nutritional Security, also proposed another support measure: from April 2020, within the scope of the PNAE, a decree was issued on the distribution of food kits for those responsible for students of public schools with the criteria of requirements defined by the management of each municipality $[29,30]$.

The network of civil society participation in solidarity actions to fight hunger was configured with the inclusion of different individuals, from associations' activists, researchers, non-governmental organizations, political entities, philanthropy support groups to citizens self-conscious about the matter. Social mobilization was highlighted, especially when emergency actions were insufficient. Initiatives promoted either spontaneously or through organized civil society, for the supply of food and/or meals in socially vulnerable communities turned out to be essential in some locations [31]. However, the population assisted by these actions is actually entitled to them; therefore, it ought to be the State's commitment to promote measures that remedy the situations of vulnerability and ensure the DHAAS, either in situations such as the current pandemic or after this episode, focusing then on structuring actions, that reduce social inequalities [32].

In the set of solidarity actions, the enhancement thereof stands out in the institution of Federal Law No. 14.016, which establishes the legal security for the donation of food ready for consumption by establishments such as hospitals, snack bars, restaurants, supermarkets, among others [33]. Food donation cannot be considered a solution to hunger, as it minimizes the problem without solving the structural issues of InSAN embedded in the history of Brazil [34].

The legal framework of emergency and structuring SAN policies and programs presents actual alternatives to alleviate the existing InSAN situation. However, in order for long-term improvements to happen, public investment needs to promote health, food and nutrition security and social assistance policies again.

\section{CONCLUSION}

The Brazilian society has historically been sensitive to the issue of fighting hunger and offers solidarity as a social value. Some initiatives, with a focus on food sovereignty and sustainable consumption, have contributed to bring about new arrangements for food supply such as short production circuits, generating a close relationship countryside-city, urban-rural, social movements and society $[35,36]$.

However, it is wise to be vigilant, as hunger is an important social marker of inequalities in the context of so many violence and rights violations in Brazil and it is the State that has the legal obligation to comply with DHAAS. Thus, society has an irreplaceable role in denouncing violations of rights and pressing the State to assume its responsibilities. 


\section{CONTRIBUTORS}

JTC OLIVEIRA participated in the conception, design, analysis, interpretation of data, writing, review and final approval of the article. AM CAMARGO participated in the conception, design, analysis, interpretation of data, writing, review and final approval of the article. BOB MACHADO participated in the conception, design, analysis, interpretation of data, writing, review and final approval of the article. AR OLIVEIRA participated in the conception, design, analysis, interpretation of data, writing, review and final approval of the article. GMR FIATES participated in the conception, design, analysis, interpretation of data, writing, review and final approval of the article. FAG VASCONCELOS participated in the conception, design, analysis, interpretation of data, writing, review and final approval of the article.

\section{REFERENCES}

1. Fundação Oswaldo Cruz. A gestão de riscos e governança na pandemia por COVID-19 no Brasil: análise dos decretos estaduais no primeiro mês: relatório técnico e sumário executivo. Rio de Janeiro: Fundação; 2020 [citado 2020 junho 26]. Disponível em: https://www.arca.fiocruz.br/bitstream/icict/41452/2/relatorio_cepedes_gestao_riscos_covid19_ final.pdf

2. Food and Agriculture Organization of the United Nations. The State of Food Insecurity in the World 2014. Strengtheningthe enabling environment for food security and nutrition. Rome: Food; 2014 [cited 2020 June 26]. Available from: http://www.fao.org/3/a-i4030e.pdf

3. Food and Agriculture Organization of the United Nations. Policy Brief: The Impact of COVID-19 on Food Security and Nutrition. Rome: Food; 2020 [cited 2020 June 26]. Available: https://reliefweb.int/report/world/policy-brief-impactcovid-19-food-security-and-nutrition-june-2020

4. Maluf RS. Tempos sombrios de pandemia e fome: responsabilidades da pesquisa em soberania e segurança alimentar e nutricional. 2020. Segur Aliment Nutr. 2020;27:e020020. https://doi.org/10.20396/san.v27i0.8659993

5. Werneck GL, Carvalho MS. The COVID-19 pandemic in Brazil: Chronicle of an announced health crisis. Cad Saúde Pública. 2020;36(5):e00068820. https://doi.org/10.1590/0102-311X00068820

6. Rodriguez-Morales AJ, Gallego V, Escalera-Antezana JP, Méndez CA, Zambrano LI, Franco-Paredes C, et al. COVID-19 in Latin America: the implications of the first confirmed case in Brazil. Travel Med Infect Dis. 2020;38:101903. https://doi.org/10.1016/j.tmaid.2020.101903

7. Mayr V, Nußbaumer-Streit B, Gartlehner G. Quarantine Alone or in Combination with Other Public Health Measures to Control COVID-19: a rapid review (Review). Gesundheitswesen. 2020; 82(6):501-6. https://doi.org/10.1055/a-1164-6611

8. Castro IRR. Má nutrição, iniquidade e a garantia do Direito Humano à Alimentação Adequada. Ciênc Saúde Coletiva. 2019;24(7):2376. https://doi.org/10.1590/1413-81232018247.15392019

9. Vasconcelos FAG, Machado ML, Medeiros MAT, Neves JA, Recine E, Pasquim EM. Public policies of food and nutrition in Brazil: from Lula to Temer. Rev Nutr. 2019;32:e180161. https://doi.org/10.1590/1678-9865201932e180161

10. Instituto Brasileiro de Geografia e Estatística. Pesquisa Nacional por Amostra de Domicílios Contínua. Primeiro trimestre de 2020. Rio de Janeiro: IBGE; 2020 [citado 2020 junho 26]. Disponível em: https://biblioteca.ibge.gov.br/ visualizacao/periodicos/2421/pnact_2020_1 tri.pdf

11. Costa, SS. Pandemia e desemprego no Brasil. Rev Admin Pública. 2020;54(4):969-78. https://doi.org/10.1590/0034761220200170

12. Salgado RJDSF, Dias MM, Souza WJ. Agricultura familiar, extensão rural e soberania e segurança alimentar e nutricional: delimitando categorias analíticas à luz da implementação do Programa de Aquisição de Alimentos no Brasil. Mundo Agrário. 2020;21(46):e137. https://doi.org/10.24215/15155994e137

13. Valente F. [tradutor]. Impacto da Covid-19 na Realização do Direito Humano à Alimentação e à Nutrição Adequadas: Relatório preliminar de monitoramento. Brasília: FIAN Brasil; 2020 [citado 2020 junho 22]. Disponível em: https:// fianbrasil.org.br/wp-content/uploads/2020/04/Relatorio-covid-19-fian-internacional-formatado.pdf

14. Trivellato PT, Morais DDC, Lopes SO, Miguel EDS, Franceschini SDCC, Priore SE. Insegurança alimentar e nutricional em famílias do meio rural brasileiro: revisão sistemática. Ciênc Saúde Coletiva. 2019;24(3):865-74. https://doi. org/10.1590/1413-81232018243.05352017 
15. Santarelli M, David G, Burity V, Rocha NC. Informe Dhana 2019: autoritarismo, negação de direitos e fome. 2019. Brasília: FIAN Brasil; 2019 [citado 2019 junho 20]. Disponível em: https://fianbrasil.org.br/wp-content/ uploads/2019/11/Informe-Dhana-2019_v-final.pdf

16. Filho WL, Brandli LL, Salvia AL, Rayman-Bacchus L, Platje J. COVID-19 and the UN Sustainable Development Goals: threat to solidarity or an opportunity? Sustainability. 2020;12(13):5343. https://doi.org/10.3390/su12135343

17. Magalhães R. Enfrentando a pobreza, reconstruindo vínculos sociais: as lições da Ação da Cidadania contra a fome, a miséria e pela vida. Cad Saúde Pública. 2020;18(Suppl):S121-S137. https://doi.org/10.1590/S0102-311X2002000700013

18. Vasconcelos FAG. Fome, solidariedade e ética: uma análise do discurso da Ação da Cidadania contra a fome, a miséria e pela vida. Hist Ciênc Saúde-Manguinhos. 2004;11(2):259-77. https://doi.org/10.1590/50104-59702004000200003

19. Araújo R, Andrade Junior H, Vecchio MCD, Monteiro PCL, Venturini AF, Pinheiro L. Caracterização e histórico das políticas públicas relacionadas à segurança alimentar e nutricional no Brasil. Ens Ciênc: Ciênc Biol, Agrárias Saúde. 2012;16(4):125-39. https://doi.org/10.17921/1415-6938.2012v16n4p\%25p

20. Périssé A, Leandro BB, Batistella CE, Barcellos C, Santos JL, Angelo JR, et al. Covid-19 e vulnerabilidades: considerações sobre proteção social nas favelas. Observatório Covid-19 Fiocruz; 2020 [acesso 2020 junho 18]. Nota técnica. Disponível em: https://www.arca.fiocruz.br/handle/icict/41456

21. Alpino TDMA, Santos CRB, Barros DCD, Freitas CMD. COVID-19 e (in) segurança alimentar e nutricional: ações do Governo Federal brasileiro na pandemia frente aos desmontes orçamentários e institucionais. Cad Saúde Pública. 2020;36:e00161320. https://doi.org/10.1590/0102-311X00161320

22. Recine E, Fagundes A, Silva BL, Garcia GS, Ribeiro RCL, Gabriel CG. Reflections on the extinction of the National Council for Food and Nutrition Security and the confrontation of Covid-19 in Brazil. Rev Nutr. 2020;33:e200176. https://doi.org/10.1590/1678-9865202033e200176

23. Sociedade do Bem Viver. Instagram. Desde 2019 conectamos campo, floresta e cidade através do bem viver e da agroecologia. 2020. [citado 2020 junho 20]. Disponível em: https://www.instagram.com/sociedadedobemviver/?hl=pt-br

24. Abedi V, Olulana O, Avula V, Chaudhary D, Khan A, Shahjouei S, et al. Racial, economic, and health inequality and COVID-19 Infection in the United States. J Racial Ethnic Health Disparities. 2020:1-11. https://doi.org/10.1007/ s40615-020-00833-4

25. Ribeiro-Silva RC, Pereira M, Campello T, Aragão E, Guimarães JMM, Ferreira AJF, et al. Implicações da pandemia COVID-19 para a segurança alimentar e nutricional no Brasil. Ciênc Saúde Coletiva. 2020;25(9):3421-30. https:// doi.org/10.1590/1413-81232020259.22152020

26. Araújo FR, Calazans DLMS. Gestão das ações de segurança alimentar frente à pandemia pela COVID-19. Rev Adm Pública. 2020:54(4),1123-33. 20.https://doi.org/10.1590/0034-761220200329

27. Paiva LH, Souza PHGF, Bartholo L, Soares S. Evitando a pandemia da pobreza: possibilidades para o programa Bolsa Família e para o Cadastro Único em resposta à COVID-19. Rev Adm Pública. 2020;54(4):1097-10. https://doi. org/10.1590/0034-761220200243

28. Freitas MDCS, Pena PGL. Fome e pandemia de Covid-19 no Brasil. Tessituras. 8(1):34-40. https://doi.org/10.15210/ tes.v8isuplemento. 18903

29. Corrêa EN, Neves JD, Souza LDD, Lorintino CDS, Porrua P. School feeding in Covid-19 times: mapping of public policy execution strategies by state administration. Rev Nutr. 2020;33:e200169. https://doi.org/10.1590/1678$9865202033 e 200169$

30. Amorim ALB, Ribeiro Junior JRS, Bandoni DH. Programa Nacional de Alimentação Escolar: estratégias para enfrentar a insegurança alimentar durante e após a COVID-19. Rev Adm Pública. 2020;54(4):1134-45. https://doi. org/10.1590/0034-761220200349

31. Jaime PC. Pandemia de COVID19: implicações para (in)segurança alimentar e nutricional. 2020. Ciênc Saúde Coletiva. 2020;25(7):2504. https://doi.org/10.1590/1413-81232020257.12852020

32. Fernandes LL. Considerações preliminares sobre a visibilidade das favelas no contexto da pandemia do COVID-19 no Rio de Janeiro: (In.) Em tempos de pandemia: propostas para a defesa da vida e de direitos sociais. Rio de Janeiro: UFRJ, Centro de Filosofia e Ciências Humanas. E-book, 2020, pp. 97-102. [acesso 22 junho 20]. Disponível em: http://pantheon.ufrj.br/handle/11422/12346

33. Brasil. Lei Federal $n^{\circ}$ 14.016, de 23 de junho de 2020. Dispõe sobre o combate ao desperdício de alimentos e a doação de excedentes de alimentos para o consumo humano. Brasília: Casa Civil; 2020 [citado 2020 junho 28]. Disponível em: http://www.planalto.gov.br/ccivil_03/_Ato2019-2022/2020/Lei/L14016.htm 
34. Finkler R, Antoniazzi N, De Conto SM. Os impactos da pandemia de Covid-19: uma análise sobre a situação dos restaurantes. Rev Tur Cidades. 2020 [citado 2020 out. 30];2:88-103. Disponível em: http://www.periodicoseletronicos. ufma.br/index.php/turismoecidades/article/view/14658

35. Braz MI, Pereira MCB. Circuitos alimentares de proximidade: conceitos, definição e práticas. Rev Geografia (Recife). 2018[citado 2020 junho 28];35(3). Disponível em: https://periodicos.ufpe.br/revistas/revistageografia/article/ view/236672/30000

36. Carvalho LD, Coelho JDC, Alves EDO, Mello AL, Balem TA, Silva CBD. O processamento artesanal de alimentos e os mercados de circuito curtos como estímulos ao desenvolvimento de sistemas de produção mais sustentáveis. Cad Agroecol. 2018[citado 2020 junho 28];13(1). Disponível em: http://cadernos.aba-agroecologia.org.br/index.php/ cadernos/article/view/84 